\title{
The Chinese Communist Party: \\ Deepening of a Crisis or Renewal \\ of the Party Base?
}

\author{
Masaharu HISHIDA
}

\begin{abstract}
Is the Chinese Communist Party showing sign of crisis due to changes in the internal and external environment? Or, is the world's largest political Party, this interest group of superlative scale, turning these changes to its advantage to recast its base and grow new and stronger roots? Following the analytical elements of organizational theory (structure, objectives, and membership of the organization), this paper examines the phases of its transformation and inspects these two different points of view calling the former one as the "dusk position" and the latter the "dawn position". Supporting "dawn position", the author glimpses CCP's “survival strategy" behind it.
\end{abstract}

\section{Keywords}

Chinese Communist Party, social change, party member, dusk or dawn, survival strategy,

\section{Introduction}

Our image of China is out of focus and scattered. One reason may be that our idea of China's "strength" is confounded, a fact that can be read as the real essence of the scattered image. As a great economic power, with the world's second largest GDP and the world's highest foreign currency reserves, China's great influence on the world economy is apparent. At the same time, however, vulnerabilities of the Chinese economy, from energy supply constraints and environmental burden to the level of technology and brand strength, accumulated debt of state-owned banks, etc., are cause for apprehension. The question in this unprecedented period of transition is whether China's political system is strong, but the "robustness" of China's political system too is subject to the same kind of scattering effect.

First of all, consider the likelihood of political change in contemporary China. 
Scenarios of future transformation have been proposed that contain predictions and expectations stemming from a variety of contexts such as modernization theory, democratization theory, theories of civil societies, social development theory, etc. ${ }^{1}$ These put forward various prospects of where the transformations of the Chinese political system are headed, and can be broadly divided into three types: (1) democratic transition scenarios, (2) collapse and chaos scenarios, and (3) adaptation scenarios.

Among the democratization scenarios (1), suggestions have ranged from specifically indicating when the shift to democracy will occur, such as Shaohua Hu's 2011 thesis, ${ }^{2}$ Henry Rowen's 2020 thesis, ${ }^{3}$ and Ronald Inglehart's 2025 thesis, ${ }^{4}$ to pointing towards a high probability of regime shift "sooner or later" without specifying an exact time, as for example Bruce Gilley and Larry Diamond. ${ }^{5}$ The common element of these scenarios believes a transition to some form of "democratic" system is inevitable. While it may not apply to all of them, these commentators often embrace pluralistic "democracy" as a universal ideal, a value to be pursued indefinitely and single-mindedly, and they cannot escape the criticism of merely having lent expression to their personal hopes by unmitigatedly applying the concept to China.

Conversely, chaos and anarchic collapse scenarios (2) can be said to focus less on the destination, i.e., some kind of "transition", and more on the "process" leading up to it. Here some commentators focus on a "crisis" of governance, as in Andrew Walder, Minxin Pei et al. ${ }^{6}$ in "Is China Democratizing?" "China's Trapped Transition", while others focus on the "collapse" of governance itself, such as Gordon Chan et al. in "The Coming Collapse of China". In particular, the latter theories of the collapse of China are in many cases the standard-bearers of the aforementioned ideological theories waiting for democratization.

Adaptation scenarios (3) are positioned between the other two, and they suggest that Chinese politics in reality is attempting in various ways to adapt to the changing

\footnotetext{
${ }^{1}$ Without going into detail, modernization theory and democratization theory look on the one hand at imbalances between "advanced" economies and "backward" politics, that is, manifestation of the contradiction between the market economy and Leninist politics, and the correlation in historical experience of development of democratization accompanying economic growth and on the other hand the observation that the socioeconomic phenomena of industrial development, population migration and a growing middle class lead to pursuit of diversification of political values.

${ }^{2}$ Shaohua Hu, Explaining Chinese Democratization (Santa Barbara: Praeger, 2000).

${ }^{3}$ Henry S. Rowen, "The Short March: China's Road to Democracy," The National Interest (Fall 1996), pp. 61-70.

${ }^{4}$ Ronald Inglehart, Christian Welzel, Modernization, Cultural Change and Democracy: The Human Development Sequence, (Cambridge: Cambridge University Press, 2005).

5 Bruce Gilley, China's Democratic Future: How It Will Happen and Where It Will Lead (New York: Columbia University Press, 2005); Larry J. Diamond, Developing Democracy: Toward Consolidation (Baltimore: Johns Hopkins University Press, 1999).

6 Minxin Pei, "Is China Democratizing?” Foreign Affairs, 77-6 (November/December 1998), pp. 68-83.

${ }^{7}$ Gordon G. Chang, The Coming Collapse of China (New York: Random House, 2001).
} 
environment despite the governance "crisis" so often pointed out, and that these efforts are progressing successfully. Denying the position of standpoints (1) and (2), as represented by David Shambaugh's "Atrophy and Adaptation", 8 Bruce Dickson's "coopting", Pierre Landry who suggests the successful control by the political elite during decentralization measures ${ }^{10}$ and also, Jing Yuejin who focuses on the "organizational technique" " of the CCP of "transition, absorption, permeation". ${ }^{12}$

Together, these scenarios bear resemblance to the "hundred schools of contending thought", but the core element at issue configuring the similarities and differences of them all is what will become of modus essendi of the Chinese Communist Party (CCP). This is because when various political and social phenomena in transitional China are studied, even if certain facets of the institutional reality are more or less well understood, the odd term always left over and unexplained is the CCP, which is the very seat of political power. The final questions key to resolving research problems is, what relations exist between the CCP and these "newborns" of the economic reform, that is, the middle class, the new bourgeois class / hierarchy, the urban white collar class, and the village elite such as the Chairman of the village committee in the rural sector, and what kind of relation are they attempting to build? Despite that the market power which vaulted China to its status as the second economic power worldwide has penetrated deeply and swept all before it, giving the impression that a capitalist system has already found footing, the CCP has reigned god-like from on high since the beginning, and continues to do so, in every aspect of contemporary China, not just in the economic arena.

Looking back, the relative sharpness of our image of China in the past was due to lack of interest and scarcity of information. But now, amid growing interest towards China by virtue of becoming a giant, China's circumstances are growing more complicated. A tsunami of information originating from China and propagated to the outside world has resulted in a "scattered" and diffuse image of China. In light of such

\footnotetext{
${ }^{8}$ David L. Shambaugh, China's Communist Party: Atrophy and Adaptation (Berkeley, CA: University of California Press, 2008).

${ }^{9}$ Bruce J. Dickson, Wealth into Power: The Communist Party's Embrace of China's Private Sector (Cambridge: Cambridge University Press, 2008).

${ }^{10}$ Pierre F. Landry, Decentralized Authoritarianism in China; The Communist Party's Control of Local Elites in the Post-Mao Era (Cambridge: Cambridge University Press, 2008).

11 Yuejin Jing, "Tenkei, Kyuushuu, Shintou: Chousen Kankyou kano Chuugoku Kyousantou no Soshikigijutu", [Transformation, Absorption and Penetration: Organizational Art of CCP under Challenge] in Masaharu Hishida, ed., Chuugoku Kyousantou no Sabaibaru Senryaku [The CCP's Survival Strategy] (Tokyo: Sanwa Shoseki, 2012), pp. 127-74.

12 Here we looked briefly at the studies of Western researchers, but in Japanese Sinology circles there is an intellectual tradition in area studies not to concern itself with divining the future, so there are very few points of view that clearly draw scenarios of political changes in China. Although there seem to be unending commercial publications based on a particular ideology or extreme sinophobia calling for the collapse of China, at least for researchers, the three patterns of scenarios adduced here are applicable.
} 
circumstances, this paper deals mainly with the CCP. As suggested at in the opening, it is the image of the CCP that ultimately will allow insight into what is now occurring in contemporary China, and, what is more, will provide the greatest tool for descrying future transformation in China.

Specifically, this paper apprehends the CCP as an "organization" and asks whether the CCP organization has become "stronger" during the period of economic reforms since 1978. Is the Chinese Communist Party showing signs of crisis due to changes in the internal and external environment? Is it even in peril of its existence? Or, is the world's largest political Party, this interest group of superlative scale, turning these changes to its advantage to recast its base and grow new and stronger roots?

In this paper, I call the former point of view the "dusk position" and the latter the "dawn position". Following the analytical elements of organizational theory (structure, objectives, and membership of the organization), we will glimpse the phases of its transformation and examine these two positions.

\section{Organizational structure}

\section{External environment}

Before considering the organizational structure, let us begin by looking at the organizational environment. In general, since adaptability to changes in the external environment is a measure of the strength of an organization, constant rapport with the external environment (communication) is essential to an organization's continued development, and the external environment of the CCP organization has grown unmistakably harsher in recent years.

Foremost among the changes in the external environment surrounding the CCP is the incapacitation of ideology, i.e., the spreading of doubts among people as to the legitimacy of socialist ideology. Having witnessed first-hand the zigzag course of political changes since the founding of the PRC, communist ideology has steadily gradually run dry as a source of organizational attraction, and since the economic reform, has reached extremes of disfunctionality. In one study, $77.7 \%$ of Party members thought that "communism is merely a beautiful ideal but is far removed from reality", and $80.6 \%$ of non-Party member respondents saw a chasm between the communist ideal and reality. ${ }^{13}$ Misgivings towards the classical socialist ideas and distrust of ideology have penetrated the general public among Party members and non-Party members alike, and this "the death of ideology" further intensifies the dusk position's sense of crisis.

\footnotetext{
${ }^{13}$ Masaharu Hishida, Shigeto Sonoda, Keizai Hatten to Shakai Hendou [Economic Growth and Social Change] (Nagoya: Nagoya University Press, 2005).
} 
Meanwhile, what is emerging as a replacement is a more quotidian idea of communism, or an image of utilitarian socialism; an overwhelming $89.4 \%$ of the Party agreed with the statement "communism improves people's lives". ${ }^{14}$ Here, the dawn position sees not "the death of ideology" but rather the socialist ideology adapted to reality, and exalts the absolute attraction held only by the organization which "sustains the progress in living standards accompanying economic growth."

On the other hand, the external image of the organization is a major environmental factor, and a decline in the image of the Party and Party members has been observed in Chinese society. Classifying the political playing field ("political status") in contemporary China into Communist Party members, Communist Youth League members, members of democratic parties and independents without a party affiliation, although it is true that Party members and Youth League members have more social prestige than other labels, in response to the question "are Party members vanguard and exemplary models?" disillusioned respondents finding "no big difference from the masses" had risen to $38.9 \% .{ }^{15}$ For the dusk position, which sees the CCP signs of crisis, this is clearly compelling evidence, and is understood as an indicator of the rapid decay of the organization's former "magnetism", i.e., the attractiveness to the masses of what can be called the brand image of the CCP as an organization.

\section{Organizational "Vacuum"}

The CCP retains a heavy coloring of Leninist tradition, ${ }^{16}$ which may be said to be the greatest pillar of its organizational structure. And while it still boasts the China's largest-scale pyramidal organizational structure, and of being the singular entity having a talent pool of the "best \& brightest", the organization has begun to show wear at the seams.

The dusk position observes that the Party's cellular organization that supported the organization in the past has grown steadily flaccid. This observation focuses on the phenomenon that after the PRC's founding, in the Mao Zedong period, the Party

\footnotetext{
14 Ibid.

15 Masaharu Hishida, Chuugoku: Kisou Kara no Gabanansu [China: Grassroots Governance] (Tokyo: Hosei University Press, 2010). Regarding the social prestige of the four political positions (Communist Party members, Communist Youth League members, democratic parties members and independents without a party affiliation), answers where $49.1 \%, 53.2 \%, 28.8 \%$ and $35.3 \%$. It is interesting that the group with the highest social prestige is not the Party, but the Communist Youth League members. Could this be the prestige be a recognition given to the "high before the fall?"

${ }^{16}$ Here, one should keep in mind that the core of Leninist party organization is the leadership and organization principles of a vanguard party, and the dictatorship of the proletariat through an alliance of workers and farmers, based on "the dictatorship of the proletariat is possible only through the Communist Party" in Lenin's works "What is to be Done?" and "One Step Forward, Two Steps Back". The rules characteristic of a workers'vanguard party and the "iron discipline" of a body of united wills also pervade the Chinese Communist Party as an organization.
} 
organization has existed in all organizations in China, the factories, enterprises, etc., but that now areas of "vacuum" have increased rapidly. On the other hand, according to public documents of the Organization Department of the Central Committee of the CCP, surveys of Party organization installations indicate a high membership rate above the $90 \%$, as shown in Table 1. Inclusion of government departments yields an astounding membership rate of $96-100 \%$, very encouraging to the dawn position, and hence the dawn position's claim that the Party organization is as strong as ever.

\begin{tabular}{l|c|c|c|c}
\hline & $\begin{array}{c}\text { Announced rate } \\
\text { of party branch(\%) }\end{array}$ & $\begin{array}{l}\text { Party } \\
\text { organization(B) }\end{array}$ & Total(A) & B/A(\%) \\
\hline Xiangzhen(township) & 99.9 & 34321 & 34324 & 99.9 \\
\hline Urban residence committee & 99.9 & 7.8 (thousand) & 7.9 (thousand) & 98.7 \\
\hline village & 99.98 & 60.5 (thousand) & 60.6 (thousand) & 99.8 \\
\hline enterprise & 99.6 & 59.5 (thousand) & 263.4 (thousand) & 22.6 \\
\hline -publicly-owned enterprise & 99.8 & 21.6 (thousand) & 24.9 (thousand) & 86.7 \\
\hline $\begin{array}{l}\text {-non-publicly-owned } \\
\text { enterprise }\end{array}$ & 99.4 & 38.0 (thousand) & 238.5 (thousand) & 15.9 \\
\hline government organ & 97.5 & 46.4 (thousand) & 57.8 (thousand) & 80.3 \\
\hline university and college & 100 & 1622 & 1622 & 100.0 \\
\hline sicence and research unit & 99.7 & 7765 & 7982 & 97.3 \\
\hline non-profit organization & 96.6 & 1.2 (thousand) & 8.1 (thousand) & 14.8 \\
\hline
\end{tabular}

Table 1: Party Organizations

Notes: 1. It is compulsry to establish a Party branch where there are more than three party members. Source: Zhongguowang [China Net] http://www.china.com.cn/policy/txt/2009-07/02/ content_18052692.htm, accessed on June 5, 2012.

However, this calculation of installation rate is made by naively placing in the denominator the number of organizations fulfilling conditions set by the Party. ${ }^{17}$ According to the "Communique on the 2009 Inner Party Statistics of the Communist Party of China," ${ }^{18}$ in the corporate sector, Party organizations have been set up in 595 thousand companies, and from here, the high membership rate of $99.6 \%$ is obtained based on the 598 thousand companies which are required by Party rules to have a Party organization structure, but dividing by 2.634 million, the actual total number of companies reduces Party installation rate to a more realistic $22.6 \%$ as shown in column $\mathrm{B} / \mathrm{A}$ of Table 1 . Broken down by ownership forms, the installation rate in public enterprises falls to $80.3 \%$, and the rate in the non-public sector (i.e., private enterprises, foreign companies) falls to $15.9 \%$. A similarly low installation rate of

\footnotetext{
${ }^{17}$ Article 29 of the Constitution of the Communist Party of China requires that primary Party organizations be formed in enterprises, rural areas, government organs, schools, research institutes, communities, social organizations, companies of the People's Liberation Army and other basic units (primary committees, general branch committees or branch committees).

${ }^{18}$ CCP Central Organization Department, June 29, 2010, Xinhua News Agency.
} 
$14.8 \%$ can be seen in non-government non-enterprise companies (private organizations and NGOs / NPOs). Although a strong demand is made for the establishment of a Party organization and union presence in the "capitalist" sector (private and foreign companies), a "new arrival" after the economic reform, Party organization construction has not progressed in line with initial targets. Even the public sector has only barely maintained the former Party cellular organization, and the grip strength it possessed in the olden days is no longer (Figure 1). The sad state of affairs is that, of the total number of 2.634 million companies in China, there is not a single Party member in 2.036 million of them (Party Central Organization Department). The Party organization's formerly proud comprehensive guidance and supervision function of Chinese "businesses" is now a thing of the past, and in many Chinese enterprises, real power in business management has shifted to the corporate and business side with a core of non-Party members. This reality of an expanding organizational "vacuum" conforms to the dusk position's sense of crisis.

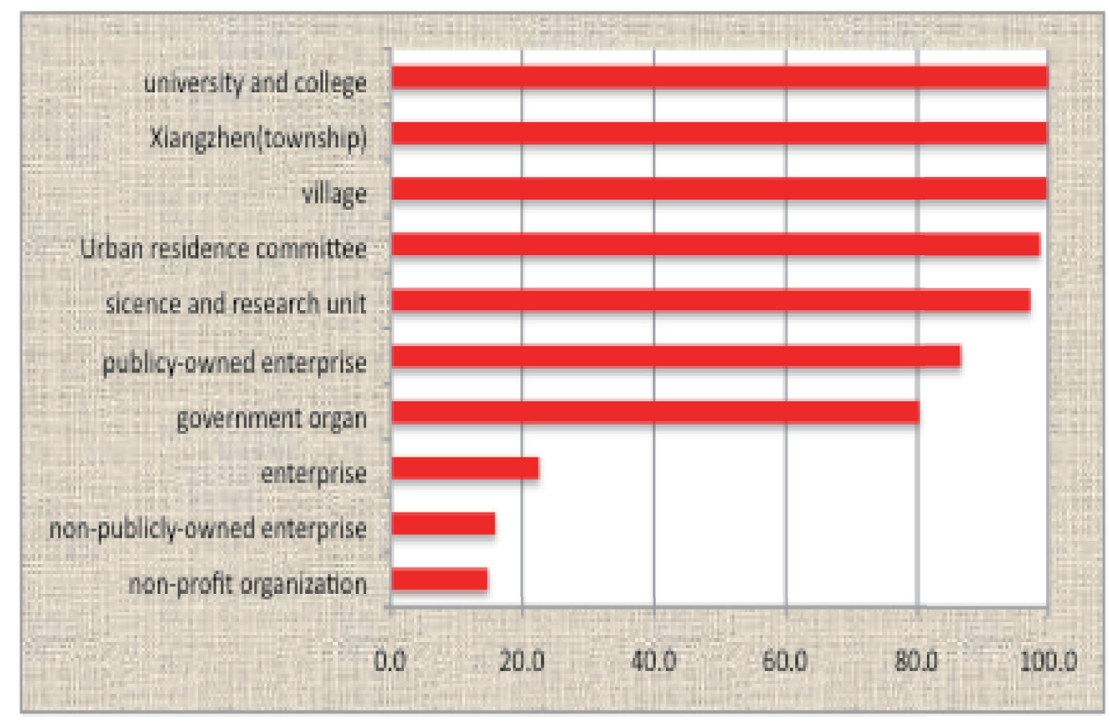

Figure 1: Party Organizations

Source: Drawn based upon data in Table 1.

The stagnation of Party organization activities has spurred this trend further. On the lowest level of Party organization in the field, even so-called "inner-Party political life" including political education, etc., has passed into formalism, and the screaming appeal can be heard from base level Party organizers that adequate mobilization cannot 
be achieved without a recreational element. ${ }^{19}$ Such a laxation of Party organizational activities means a decline in ideology, as seen earlier. The very "field" of what has served as the "magnetic field" by which the CCP's force of attraction was exerted is disappearing. So, from this, said judgment of the dawn position must be discarded, and the dusk position's perception of crisis is strengthened.

\section{Organizational Objectives}

Organizations are originally established in order to achieve certain objectives, and the status of those set objectives is what essentially regulates the organization. This is because it is the values, ideas and ideals held up as the organization's objectives speak to and resonate with people who then rally to and become members of the organization, and it is only for the realization of these objectives that organization-internal systems and rules are put into place and organizational activities and mechanisms are deployed.

\section{Organizational objectives}

So what are the objectives of this organization? Let us try to extract the CCP's organizational goals from the Party platform. At the National Congresses spanning from the Party's formation in 1921 through the 17th Congress, the Party Constitution has undergone revisions and corrections and the organization's objectives have been established. In the "Platform of the Communist Party of China" adopted at the First National Congress of the Communist Party of China held in Shanghai in July 1921, in which "realization of class struggle" was considered to be the "ultimate aim of struggle". A Party Constitution comprising six chapters and 29 articles was adopted for the first time at the Second Party Congress of July 1922 in Shanghai. However, at the Sixth Party Congress held in Moscow in June and July 1928, the CCP was made a "chapter of Comintern," and thus was largely heteronomous and lacking the autonomy to set its own objectives: the Party Constitution at the Seventh Party Congress (April to June 1945, Yan'an) was declared to be "the first established independently and on a basis of self-determination". ${ }^{20}$

From the founding to the Seventeenth Party Congress, the Party Constitution has been_revised ten times. The "realization of communism" has changed from "ultimate goal" to "goal", "ultimate objective", and, since the Sixth Party Congress in 2002, to "highest ideal".

The dusk position interprets this change as the lapse of the "realization of

\footnotetext{
${ }^{19}$ Hishida, Chungoku: Kisou Kara no Gabanansu, op. cit.

20 Zhonggong Dangshi Cankao Ziliao [Reference Materials Relating to the Chinese Communist Party History] , p. 569.
} 
communism" from an organizational objective to the level of a mere "ideal", and in particular finds supporting evidence for this view in the deletion since the Sixteenth Party Congress in 2002 of the phrase "socialist society will necessarily replace capitalist society", so glorified in the Party Constitutions of the past. The alteration of the objective indicates not only a change in its self-perception as an organization, but also uncovers a further deepening of the crisis because of the loss of attractiveness of this organization that has gone the route of distrust of ideology, as glimpsed in the previous section. In addition, if new and candidate members join not because of their agreement with the rhetoric of the organization's publicly presented objectives, then the facade of the organizational objective must indicate a fatal organizational crisis.

On the other hand, the dawn position will consider this to show the high level of pragmatic adaptability to changes in the outside environment, in particular, the change in practicability of realizing a communist system, and see it as a mark of the organization's strength. That is, the new and unspoken collective organizational goal is now representing and securing Party members' interest, including that of new members, and it is this "silent consensus" which the dawn position sees as strengthening the organization's base.

For that matter, the organization's auto-regulated self-image itself underwent a sea change in 2001. Simply put, this change is the "Three Represents" theory. The "Three Represents" theory states that the Chinese Communist Party represents (1) the requirements of development of China's advanced productive forces, (2) the development of China's advanced culture, and (3) the fundamental interests of the overwhelming majority of the people in China. In the Party Central Committee Report (Political Report) of the Sixteenth Communist Party Congress of November 2002 to the traditional definition of the Party in the Party Constitution preamble as "the vanguard of the working class" was added "vanguard of the Chinese people and the Chinese nation", thereby seeking to broaden the Party base to the "overwhelming majority of people."

Evaluations of this turnabout are divided between the dawn and dusk positions. Whereas the former lauds the organization for expanding its support and shifting from a party of class to an inclusive (catch-all) party, the former renders a negative judgment, considering that the $\mathrm{CCP}$, in opening the Party to private entrepreneurs, i.e., bourgeois capitalists, has negated its past self-definition as an alliance of workers and farmers and has fallen to a new elitist Party serving only the elite.

\section{Organization Members}

It is often pointed out in management theory and organization theory that people are 
the ultimate elements supporting an organization, and the recent transformation of membership in the CCP shows some striking features.

\section{Membership}

The scale of Party membership has steadily expanded, and the latest data published puts membership at 80.269 million as of late 2010, an increase of 2.274 million over the previous year. ${ }^{21}$ Compared with the total number of members at the end of 2009 , 77.995 million, itself an increase of 2.064 million over the previous year's membership of 75.931 million, we see that even though the rate of increase is slowing; 2008 showed an increase of 0.7733 million over the previous year of 74.153 million, the organization is still in a trend of expansion. The absorption rate, i.e. the ratio of CCP membership to the general population, is $5.8 \%$ and there is no change in the fact that the political group boasts of the largest number of members in the world and one of the highest absorption rates. This over-5\% organizational absorption rate must seem heartening to supporters of the dawn position. Even at its height, the ratio of Liberal Democratic Party members in Japan to the total population was never more than about $1 \%$ and that of the Communist Party of the Soviet Union was less than $1 \%$ so that, except certain small countries like Albania and North Korea, the high CCP absorption rate can be viewed as extraordinary.

Although the geographical distribution of the absorption rate is not necessarily clear; from the figure putting the total number of Party members in the city of Shanghai at the end of 2009 was 1.6942 million, or $8.82 \%$ of the permanent population of Shanghai ${ }^{22}$ we get an inkling of the higher absorption rates in the urban sector, especially in large cities, and we can see an "urban Party" whose member base is in the urban sector.

However, a different picture emerges upon a more detailed examination of the age structure and profile of Party member occupation and class distribution. ${ }^{23}$

\footnotetext{
${ }^{21}$ Xi Jinping zai Quanguo Zuzhibuzhang Huiyishangde Jianghua [Xi Jinpin's Speech in National Conference of Party Organization Department ] http://theory.people.com.cn/ GB/82288/83849/83857/17340823.html_accessed on June 4, 2012.

22 "Shanghai meibairenzhong you Zhonggong Dangyuan 8.82 ming [In Shanghai 8.82 Party members in every hundred people]," Jiefang Jun Bao [People's Liberation Army Daily] (July 9, 2010).

${ }^{23}$ In this connection, the total number of Party members in Fujian Province is 1.754 million $(59,000$ more than the previous year, as of late 2009; source: "Daizhi 2009 niandi Fujiansheng Gongchang Dangyuan 175.4 wanming [1.754 million Party members in Fujian Province at the end of 2009 ]," Fujian Ribao [Fujian Daily] (30 June 2010); In Guizhou Province there were 1,472,579 members (44,703 more than the previous year). Source: "Daizhi 2009 niandi Guizhousheng Gongchang Dangyuan 1472579 ming [1472579 Party members in Guizhou Province at the end of 2009 ]," Guizhou Ribao [Guizhou Daily] . Thus, from the total populations of Fujian (35.81 million) and Guizhou $(39,764,800)$, the Party member absorption rate is calculated to be $4.8 \%$ and $3.7 \%$, respectively.
} 


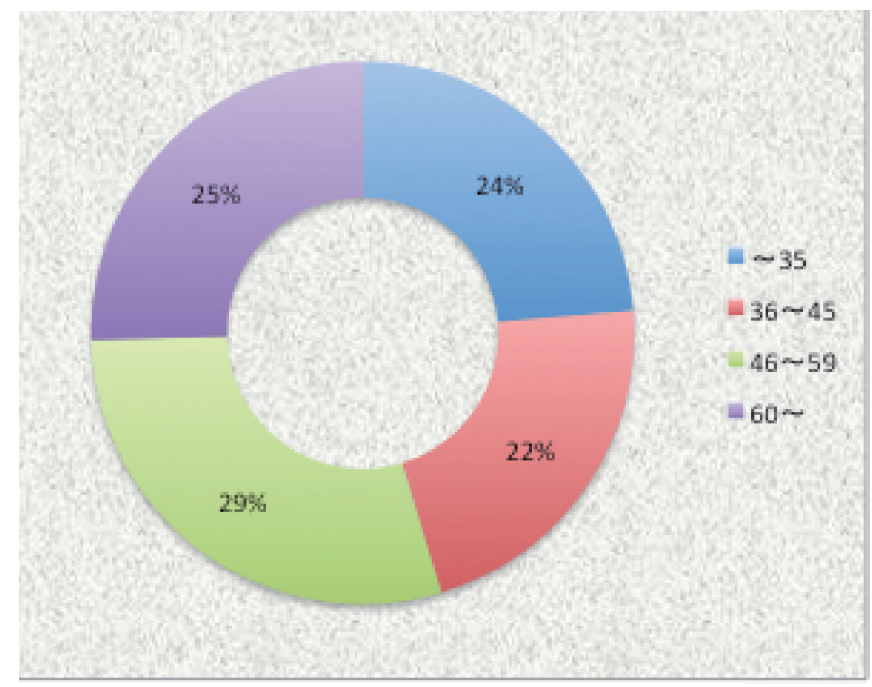

Figure 2: Party Member Profile by Age Source: See Table1.

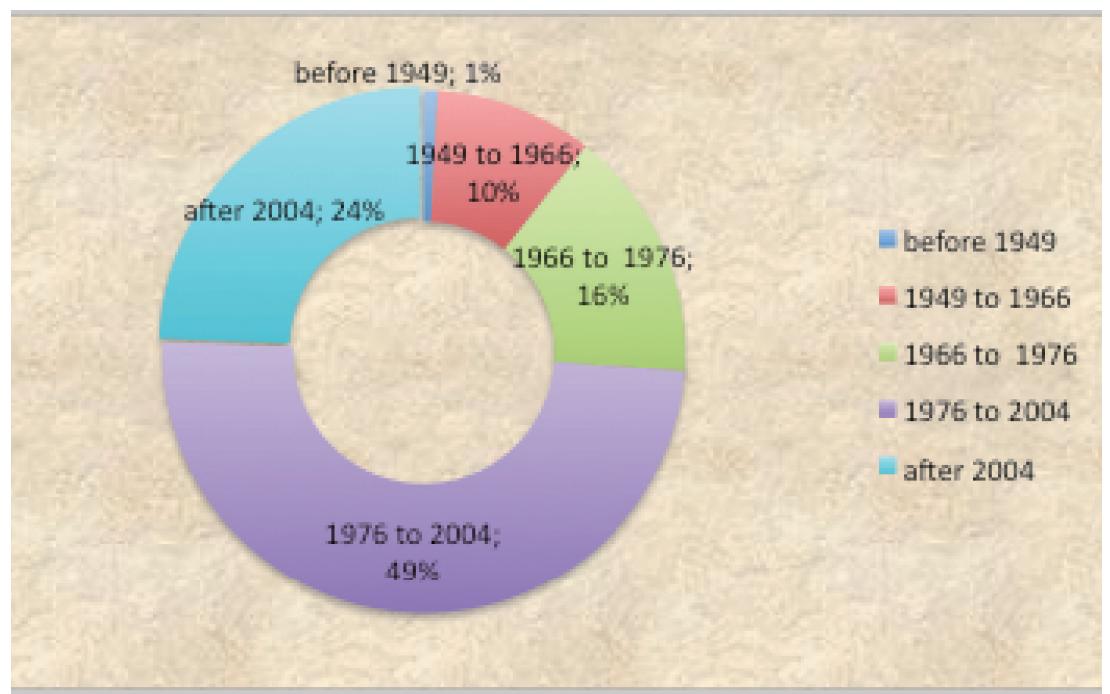

Figure 3: Party Member Profile by Period of Joining the Party

Source: See Table 1.

As seen in Figure 3, the member age structure is a distribution across each generation. Examining when the members joined the Party, about three quarters are members who joined after the economic reforms, after the end of the Cultural Revolution; only one quarter of the total are veteran members that have accompanied the Party through the turbulence of the PRC's history since its founding (see Figure 4). 


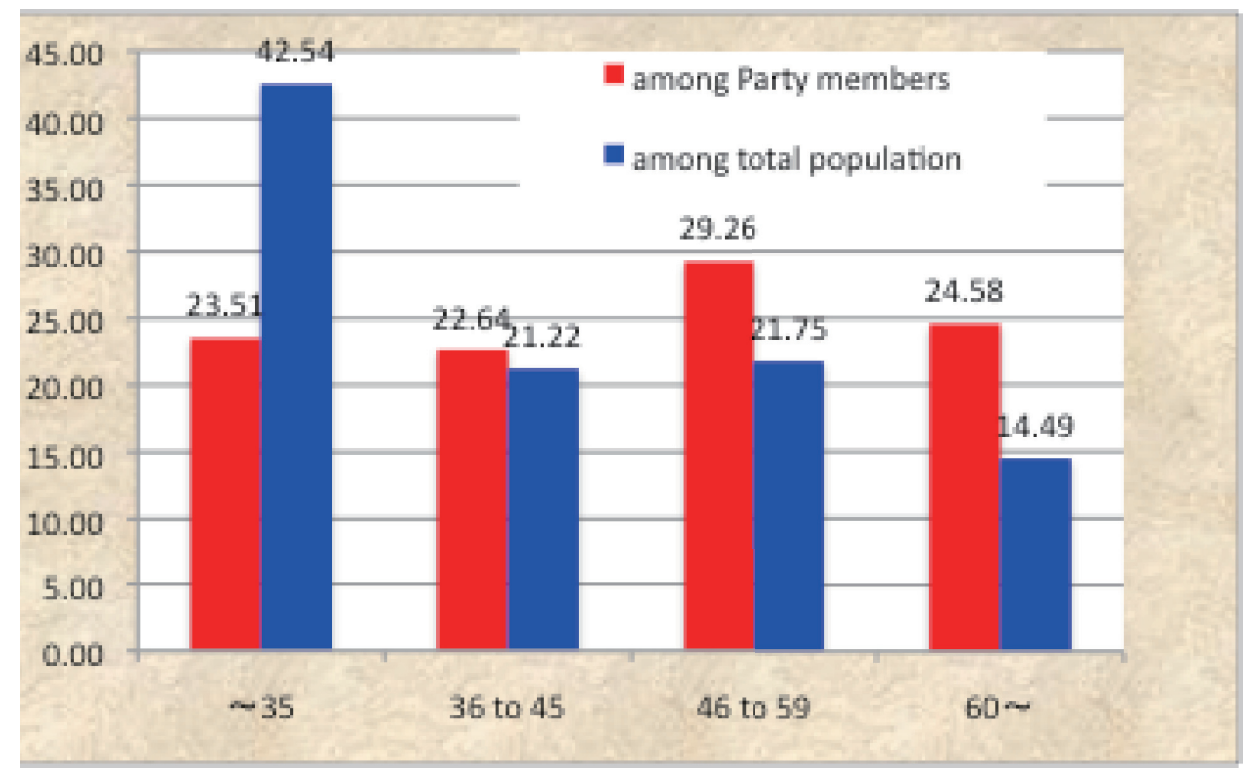

Figure 4: Comparison of Age Distribution

Source: Zhongguo 2000nian Renkou Pucha Ziliao [China Census Data 2000] (CD-ROM), Zhongguo Tongji Chubanshe [China Statistic Press], 2005 March and Zhongguowang [China Net] http://www.china.com.cn/policy/txt/2009-07/02/content_18052692.htm accessed on June $5,2012$.

However, compared with the share of the general population of the each age group, it becomes apparent that the CCP is over-dependent on its senior members. In other words, the absorption rate among young people aged 36 and below, a group now making up nearly half of the population, is only some $20 \%$ whereas the age group of 46 and above is overrepresented in CCP membership. It is evident that the organizational structure of the Party is centered on the older generation and is marked by an underrepresentation of young people.

Next we will look at the occupation and class profiles of Party members.

As seen in figure 5, members having a background as workers or farmers make up only $28.1 \%$ of total members, so the provision of a "class party based in a workers' and farmers' union" stops at the rhetoric of the Party's constitution. The main members are from, or pretend to be from, the so-called establishment, three quarters of which is made up of managers and students. Further, Figure 5 contrasts the proportions of occupations and classes represented in Party membership and shares in the population at large, and once again we clearly note the underrepresentation of CCP members among workers and farmers and the overrepresentation among cadres and technocrats. Here, the dusk position does not stop at a theoretical criticism of "Three Represents 


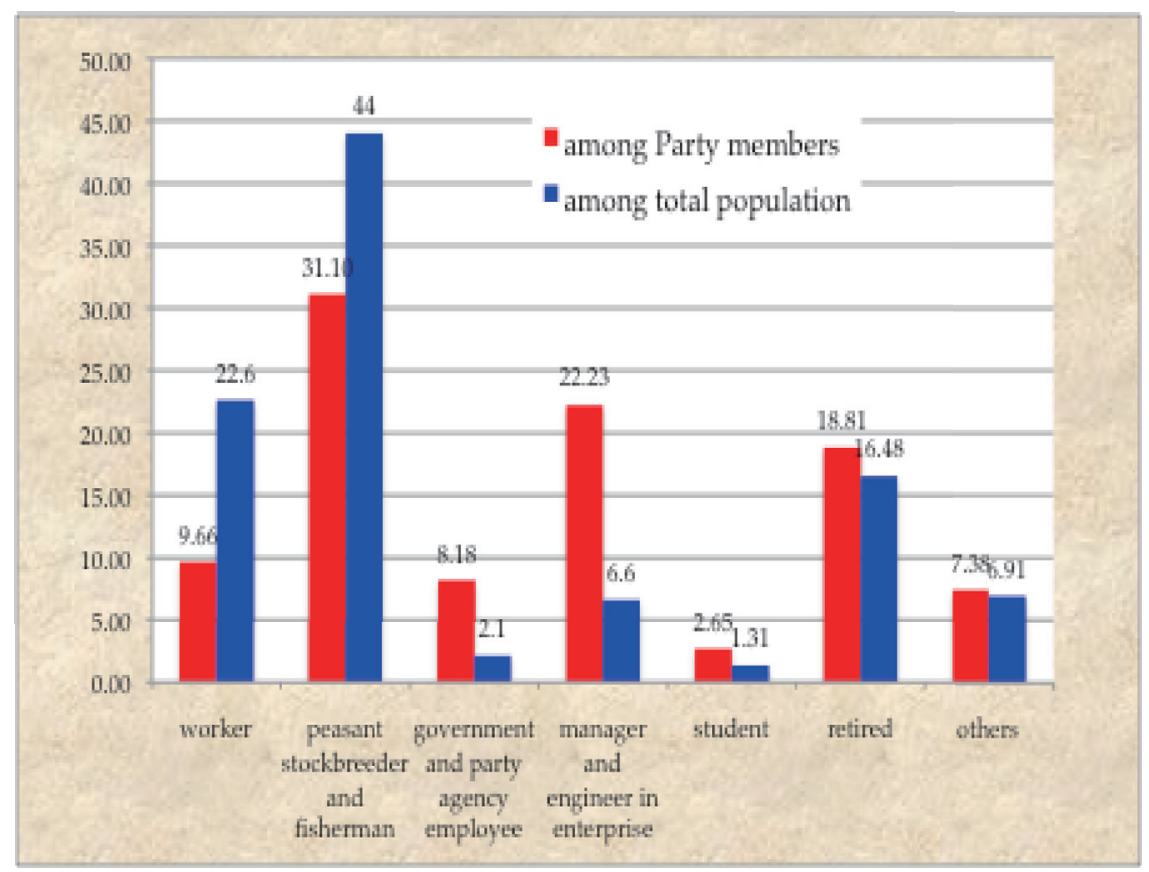

Figure 5: Comparison of Occupational Distribution

Source: See Figure 4.

Theory" but sees signs of crisis in the actual condition of the organization that has betrayed its traditional class base and has become an alliance of the victors of the economic reform, a party of the elite class.

Naturally, the Party is focusing its efforts on recruiting the brightest of the youth. Figure 6 contrasts the ratio of attributes of current members with the distribution of the same attributes among "recruitment members." "Recruitment members" refers to the focus of active recruitment operations on the part of the CCP, and "member development operations" is defined as "the entire process of preferentially training, educating and observing outstanding persons from the population that dedicate themselves to socialism and communism, preparing them to meet conditions of Party entry to integrating them into the Party." 24 Applicants for Party membership at the end of 2010 were as many as 21.017 million of whom eventually 10.555 million became active Party members. On the one hand, the emphasis of recruitment is clearly on young people aged under 35 and women. On the other hand, it can be said that obtaining members with a background of higher education has a certain effect.

\footnotetext{
${ }^{24}$ CCP Member Recruitment Operation Bylaws (trial).
} 


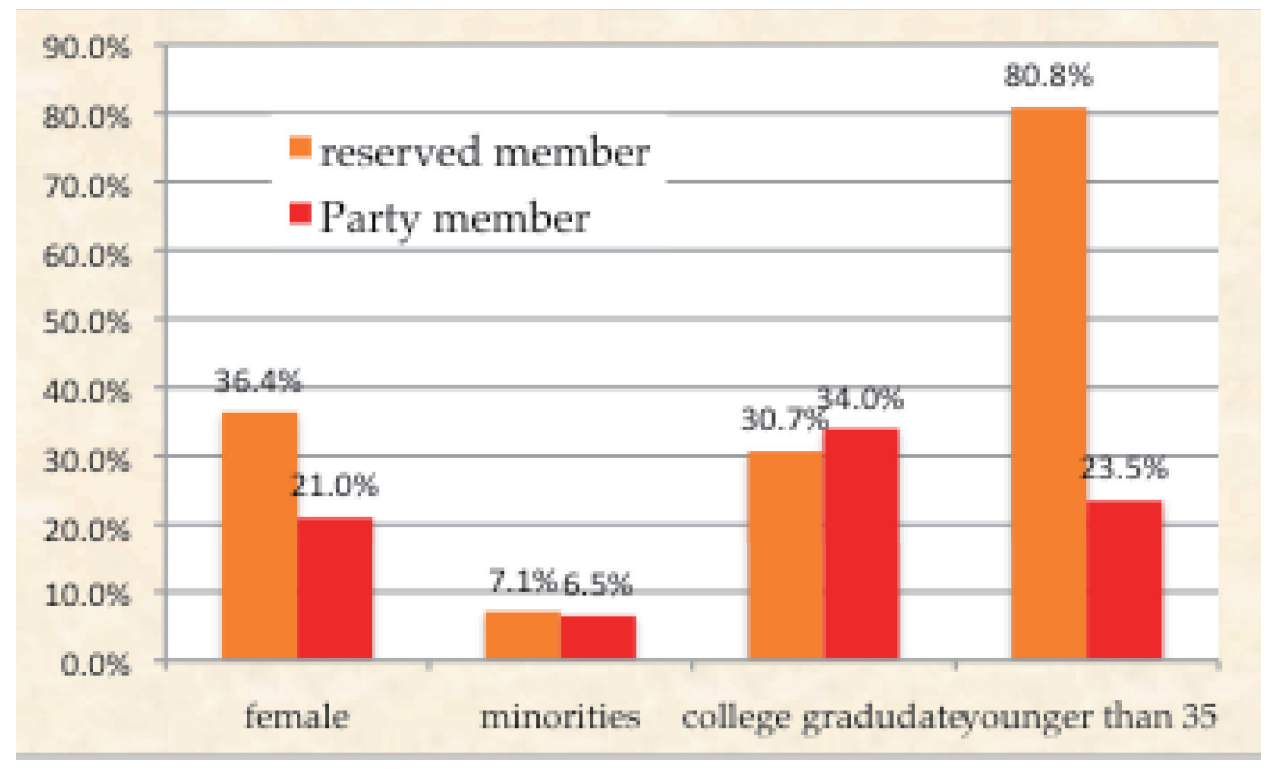

Figure 6: Comparison of Reserved Members and Current Members

Source: See Table 1.

The overrepresentation of the establishment as described above is in part a product of the success of the CCP's active recruitment operations, and the dawn position will see the strength of this organization that rallies people together with the organizational goal of sharing and maximizing their newly established interest.

\section{Motivations for joining the Party}

So what is it that members expected when they joined, and what is it that new members expect upon joining the Party? Given the ideological crisis described above, it has long since been pointed out that the ideology as a motivation for joining the Party is waning and recent studies that we ourselves have carried out have put this into stark relief. ${ }^{25}$ Contrasting the difference among generations, the percentage of Party members who "joined the Party because of a belief in the ideal of communism" has fallen precipitously with each generation: compared to $51.2 \%$ of Party members aged 50 and above who agreed with the statement, only $42.9 \%$ of members in their $40 \mathrm{~s}$, $31.5 \%$ of members in their $30 \mathrm{~s}$, and $21.2 \%$ of people in their $20 \mathrm{~s}$ did so, which is about a 10 point drop in each succeeding generation.

Instead, there is an increasing trend of people being motivated to join the CCP for "self-realization." Whereas this is true of only $4.9 \%$ of persons aged 50 and above, it is true for $15.3 \%$ of Party members in their 30 s and for as many as $18.2 \%$ of Party

${ }^{25}$ Hishida, Sonoda, Keizai Hatten to Shakai, op. cit. 
members in their 20s. Further, among Party members in their 20 s, nearly $10 \%$ joined the Party because of the practical consideration of being "advantageous in finding employment." If it is true that the centripetal force of the CCP is changing from "the ideal of communism" to utilitarian benefits such as "self-realization" or finding employment, ${ }^{26}$ then the relation between the Party and the Party members cannot help but change too. If the Party cannot ask members to conform to the rhetoric of organizational objectives held up in the Party constitution, etc., then the Party members will ask of the Party only the brand value of a Party membership certificate, in other words, employment, promotions, and opportunities to accumulate wealth. The colorings of a simple interest group will grow thicker, and, necessarily, the cohesive force of the Party organization will continue to weaken. In the view of the dusk position, the organization's laxation, discernable from the joining motivations of its members in combination with the hollowing out of the organizational objectives, is a sign of a fatal organizational crisis.

\section{Summary - Dusk or Dawn?}

The "scattered reflection" mentioned in the opening refers to the phenomenon in which light reflected from an object's surface scatters in all directions due to the microscopic irregularities on the body. The cause of scattering is firstly the object itself. However, even more than a problem of the "surface irregularities" of China itself as the reflecting body, the "scattering" of our image of China may be a problem of the "light" that we shine on it. In other words, it may well be a function of our own vantage point and position on China. For example, the "Arab Spring," beginning in Tunisia, coursing through Yemen, Jordan and Bahrain, unseating Mubarak of Egypt, the "leader of the Arab world," has continued its spread to Libya; but oft spoken-of premonitions and expectations that a "Jasmine Revolution" will presently swell up and sweep through China is just such a point of view.

At this juncture, let us summarize the dusk and dawn positions. Both the dusk and dawn positions see the CCP's transformation as an organization. Both the internal unifying force and the external support that have held up the organization in the past are quickly wearing down due to the expiration of socialist ideology. The dusk position then shines the light of "crisis" onto this state of affairs, asserting that for the CCP, by embracing too many external elements and gradually losing its magnetic force as well as the magnetic field by which it was exercised, is on a dead-end path to self-destruction. But whereas the dawn position, shining the light of "adaptation," sees the re-setting of the organization's objective as a laudable adaptation to reality, the dusk position sees

${ }^{26}$ Kazuko Kojima, "Eriitosou ni Okeru Tou no Sonzai" [CCP's Existence in Elite Strata] in Masaharu Hishida, ed., Chungoku Kyousantou no Sabaibaru Senryaku [The CCP's Survival Strategy] (Tokyo: Sanwa Shoseki, 2012), pp. 373-396. 
the downgrading of a clear "goal" to the level of a mere "ideal" as a crisis of the very legitimacy of the organization's existence. Also, the dusk position judges that the large change in membership to what may be called a "coalition of victors" of the economic reforms shows the extreme situation of the organization's transformation and crisis.

However, after an examination of both positions, the "adaptation" scenario (3) may more clearly explain the remarkable CCP organizational transformation.

\section{Preventive survival strategy}

As far as the reasoning behind this, the following points can be made at present. First, it is important to emphasize the process in which the CCP itself has consistently been an active agent in this transformation, or "organizational crisis." The CCP was certainly not embroiled in this "crisis" situation unwittingly, nor is it now casting about for temporary fixes. Rather, the CCP has been a careful, active and daring leader throughout the transformation, and has controlled it. The pattern of economic development not involving political transformation is classically symbolized by the "Beijing Consensus" touted by China. ${ }^{27}$ Furthermore, preventatively squashing "objectors" and the growth of an opposition is important. The CCP's foresight in actively embracing and incorporating potential opposition forces and actively transfiguring itself was extremely strategic.

Using Peter Senge's concept of the Learning Organization (LO), now a popular resource-based strategic theory of management, the CCP's strategic transfiguration is re-defining itself as a "learning party". ${ }^{28}$ A "learning party" facilitates autonomous learning of its members and, by sharing the results within the entire organizational body, realizes a high level of competitiveness. It is an organizational model in contrast to conventional authoritarian organizations (that "manage"). "Management organizations" are efficiency-oriented, whereas the central theme in learning organizations is finding and solving problems, with members expected to understand a situation, such as customer needs, and to learn continuously, from locating where the problem is all the way to finding solutions. ${ }^{29}$ The plan to promote the

${ }_{27}$ Masaharu Hishida, "Chuugoku: Zenkyuuka no Chouji?" [China: Globalization's Darling?] in Yuji Suzuki, Kazumi Goto, eds., Guroubarizeishon to Guroubaru Gabanance [Globalization and Global Governance] (Tokyo: Hosei University Press, 2009), pp. 243-276.

28 Under Jiang Zemin after 2002, calls were made to construct a "learning organization", but at the 90th anniversary of the Party's foundation, a campaign for construction of a learning organization was full underway, and the related documents are too numerous to comprehensively list here. For an introduction to this movement, see Zhu (2012).

29 The founder of Learning Organization theory, Peter Senge (MIT Sloan School of Management, founding chairperson of SOL: Society for Organizational Learning) is a classic Western management scholar who has taught the theory and practice of "organizations that learn" to Western corporations like Ford, DEC, Apple, Proctor \& Gamble, AT\&T, Royal Dutch Shell, and Harley-Davidson. In China, billed as "the most outstanding teacher of management in the modern age", he has become more involved, delivering many academic lectures since his first visit to China in September 2002, at Peking University, Tsinghua University, the Communist Party of China Central Committee's Party 
construction of the Party organization from the very base using the concepts and methods of the "learning organization" can serve as an indication of the great transfiguration of the CCP since adopting the "Three Represents Theory". Presently, nothing prevents judging this bold "preventative survival strategy" a great success.

Furthermore, the potential "objectors" or opposition clearly makes up part of the present system and is by no stretch a "challenger" resisting the present system from the outside. Political reform is always generated from the desirable divergence of political values concomitant with diversification of social consciousness, but at the present time, no large splits in political values are in sight. The largest potential threat, the values consciousness of private entrepreneurs, can be seen to be largely in phase with those of the institutional leaders in the same locales. ${ }^{30}$

\section{Conclusion}

Let us attempt to sketch a future image of the CCP organization. Will a new transformation visit the present mode of existence of the CCP? Let us review this question through the context of a potential propagation of the Arab Spring to China as a "Jasmine Revolution," as mentioned earlier.

Sampling as structural elements of a "Jasmine Revolution", spreading sentiment of discontent centered in the young generation from the population explosion and "net power" of social networking services such as FaceBook and Twitter, both must be abandoned in the reality of today's China. Certainly, many social studies do show the existence of discontent in China, and the Chinese authorities themselves report with a sense of panic of "social outbreak incidents" and "collective incidents." However, the existence of discontent is a normal state, as societies without discontent are impossible. The question is how far discontent has penetrated, has the level of dissatisfaction exceeded that of hope, and, how far have preventative safety measures been taken against "conceivable" scenarios?

School, etc.. This is a noteworthy sign of further transformation of the CCP.

30 Bruce J. Dickson, Wealth into Power: The Communist Party's Embrace of China's Private Sector (Cambridge: Cambridge University Press, 2008). 


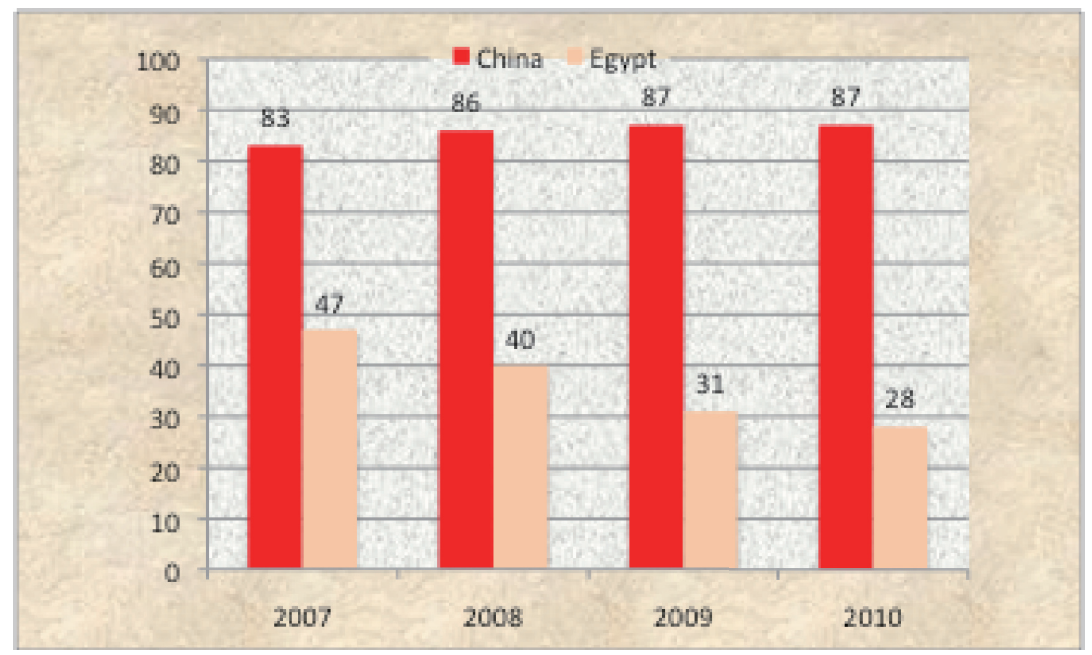

Figure 7: Satisfaction with the Country's Direction

Source: Drawn based upon the data downloaded at http://www.pewglobal.org/category/ datasets/ Spring 2010 Survey Data, Pew Research Center.

Figure 7 compares Egypt's and China's direct influence from the "Jasmine Revolution" based on a survey conducted by Pew Research in 26 countries. It shows that the overwhelming support and positive expectations for China's direction puts it in a completely different dimension from the example of Egypt.

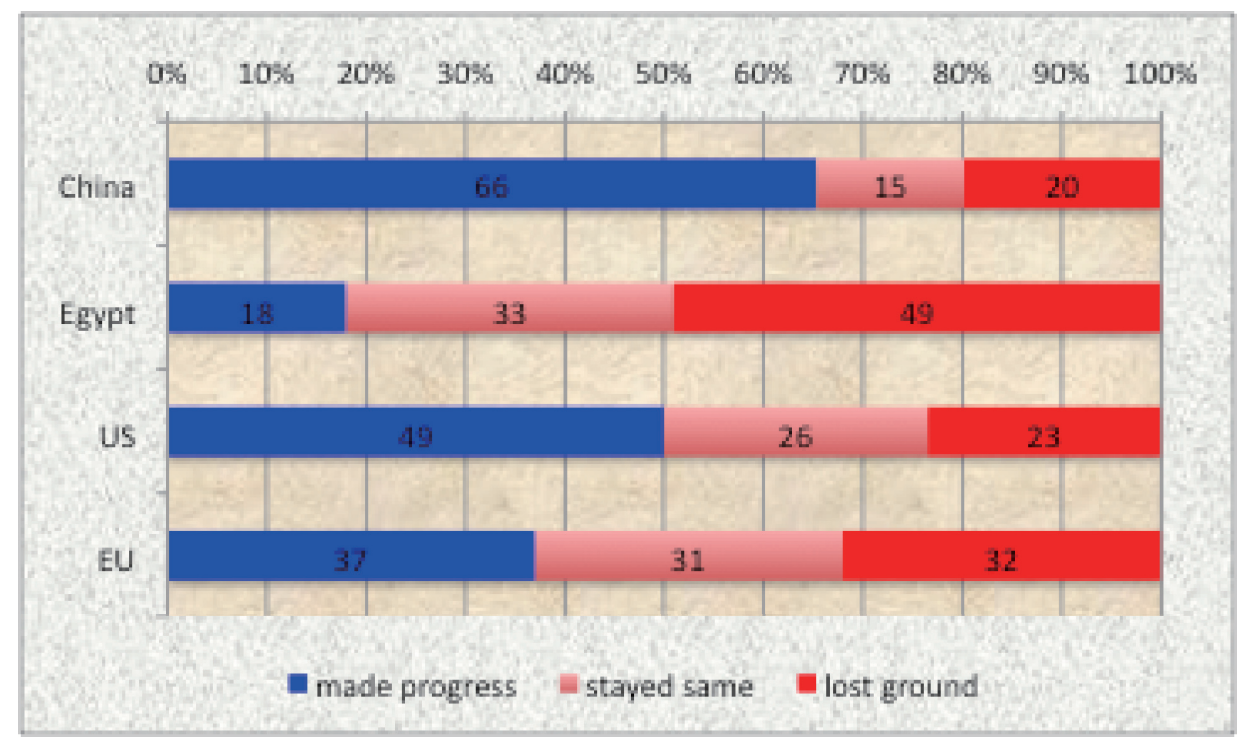

Figure 8: Perceived Progress Over the Past 5 Years

Source: See Figure 7

For example, looking at perceived living standards in the past five years, over $60 \%$ in China reported "progress," whereas over half of the respondents in Egypt reported 


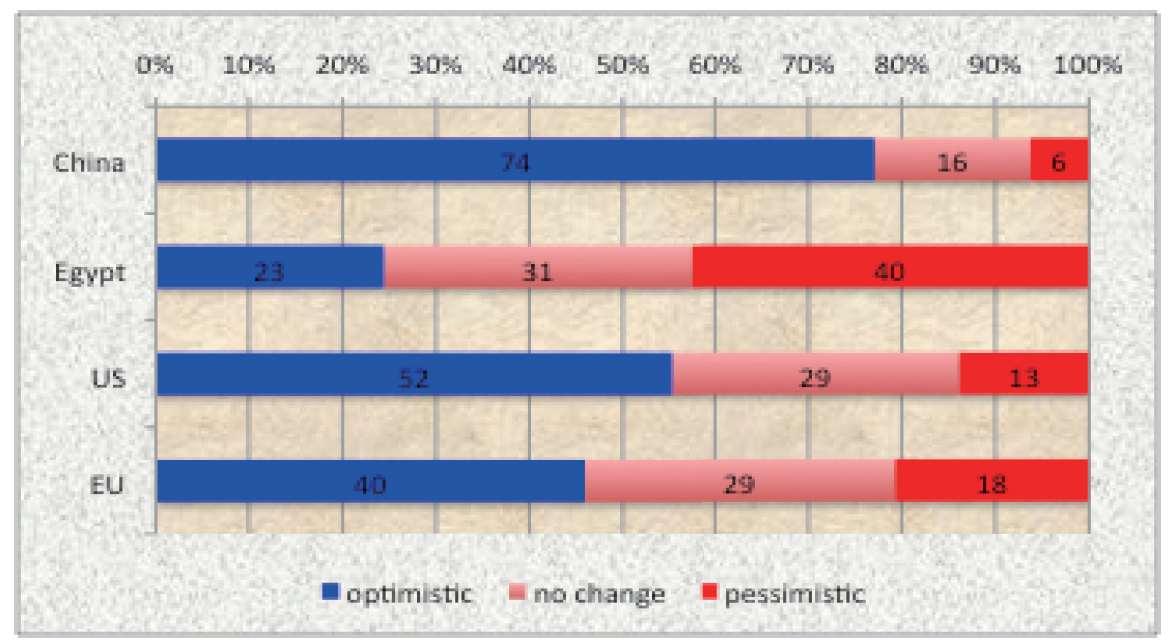

Figure 9: Expected Progress Over the Next 5 Years

Source: See Figure 7.

that they "lost ground." As it becomes apparent from Figure 8, China and Egypt arevery different in this respect. Similarly, when Chinese were asked about their expected progress in the coming five years, "optimistic" overwhelmingly surpassed "pessimistic." 31 This should re-affirm the effect of the transition towards an image of utilitarian socialism, the idea of socialism perceived on a daily basis as an embodiment of the phrase "communism improves people's lives". Because the people of China on the whole still look forward with hope for tomorrow, they are far from being enticed by the fragrances of a "Jasmine Revolution".

Further, even the "net power" that receives so much hype in discussions about a "Jasmine Revolution" has limited effect in contemporary China. Does it stop at being a means for sending and receiving information, or is it a powerful force in its aspect of group mobilization and formation of new organizations? From the very beginning, the construction of an IT society in China has been led by the state. ${ }^{32}$ While the government did announce and promote the construction of an information society, the existence of the national project of internet registration and monitoring known as the

31 James Bell, "Upbeat Chinese May Not Be Primed for a Jasmine Revolution," Pew Global Attitudes Project (11 March 2011), at <http://pewresearch.org/pubs/1945/chinese-may-not-be-readyfor-revolution> (searched date: 28 April 2012).

32 Following joint research between Germany and the Chinese Institute of Computer Applications (ICA) of Beijing in 1986, after a ten-year exploratory phase with Tsinghua University and Peking University, the Chinese Academy of Sciences Institute of High Energy Physics, etc., international recognition of an internet connection was obtained in April of 1994, and from January of 1996, the internet connection business was started by government-led enterprises such as CHINANET, CSTNET (China Science and Technology Network), CERNET (China Education and Research Network) and CHINAGBN (China Golden Bridge Network); connection other than through official providers is nearly impossible. 
"Golden Shield Project" shapers known as the "fifty cent party" have been an extremely effective means of resisting permeation of the "Jasmine Revolution." Even this Janus-faced dealing of the Chinese authorities can be considered part of a "preventative survival strategy" that anticipates the importance and danger of the IT revolution. Whatever the case, China's "netizens," having lived through the Tiananmen incident, already have a degree of immunity.

Finally, if we are asking about the resolution of the future transformation of the CCP organization, it will ultimately depend on the continued value of the "Party membership ID card." In other words, it will depend on the people's dependence on the CCP. Predictions can be made in which the "Party membership card" is stripped of value, such as outside pressure scenarios (in which, due to goals of international cooperation, traditional priority domestic policy measures are abandoned with the result of a loss of confidence in the Party and Party line) or scenarios of external bestowal (appearance of a new actor or situation capable of giving practical benefits in addition to the CCP or at a level above that of the CCP). However, the above-mentioned "preventative survival strategy" would naturally foresee these scenarios and largely limit the possibility of their occurrence. Consequently, the process of recasting the organizational base of the $\mathrm{CCP}$, as seen by the dawn position, has been a success, and after its morphogenesis as a learning organization, the new CCP organization will continue the trend of stabilization.

Even so, political change is not something that occurs cumulatively, governed by past experience, accompanied by signs and in planned harmony. It may occur suddenly, with no warning at all. The reflecting body of contemporary China is full of unknown elements, and the possibility of a tearing asunder of the current balance cannot be excluded. As in Japan, recently shaken by a horrendous disaster, we must bear in mind that "unanticipated" transformations may occur at any time.

\footnotetext{
33 In 1993, the Chinese government set a national IT strategy called the "Golden Projects" oriented towards the digitalization of finances and bringing the government online, and one of these was the "Golden Shield" aimed at creating an information management system for the Public Safety Department. In September 1998, the National Public Safety Department proposed the Golden Shield Project, which was ratified by the State Council in April 2001, and now blocks harmful sites, manages a file system (private information management) and monitors access information.
} 


\section{References}

Chang, Gordon G., The Coming Collapse of China (New York: Random House, 2001).

Diamond, Larry Jay, Developing Democracy: Toward Consolidation (Baltimore: Johns Hopkins University Press, 1999).

Dickson, Bruce J., Red Capitalists in China: The Party, Private Entrepreneurs, and Prospects for Political Change (Cambridge: Cambridge University Press, 2003).

Dickson, Bruce J., Wealth into Power: The Communist Party's Embrace of China's Private Sector (Cambridge: Cambridge University Press, 2008).

Gilley, Bruce, China's Democratic Future: How It Will Happen and Where It Will Lead (New York: Columbia University Press, 2005).

Gore, Lance L.P., The Chinese Communist Party and China's Capitalist Revolution: The Political Impact of Market (New York: Routledge, 2011).

Hishida, Masaharu, “Joshou: Chuugoku Kyousantou no Sabaibaru Senryaku” [Preface: The CCP's Survival Strategy] in Hishida, Masaharu, ed., Chuugoku Kyousantou no Sabaibaru Senryaku [The CCP's Survival Strategy] (Tokyo: Sanwa Shoseki, 2012), pp. 1-35.

— "The Morphogenesis of the CCP: Organizational Issues," in Hishida Masaharu, ed., China's Trade Unions -- How Autonomous Are They? A Survey of 1811 Enterprise Union Chairpersons (London: Routledge, 2009).

,Chuugoku: Kisou karano Gabanansu [China: Grassroots Governance] (Tokyo: Hosei University Press, 2010).

__ , "Chuugokku: Zenkyuuka no Chouji?" [China: Globalization's Darling?] in Yuji Suzuki, Kazumi Goto, eds., Book Title in Japanese [Globalization and Global Governance] (Tokyo: Hosei University Press, 2009), pp. 243-276.

_ , "Chuugoku Kyousantou no Metamorufosisu" [The Metamorphosis of the CCP] in Watanabe, Toshio, Terashima, Jitsuro and Zhu, Jianrong, eds., Daichuukaken no Jitsuzou [Real Image of the Greater China] Tokyo: Iwanami Shoten, 2004), pp. $257-$ 262.

Hishida, Masaharu, Sonoda, Shigeto, Keizai Hatten to Shakai Hendou [Economic Growth and Social Change] (Nagoya: Nagoya University Press, 2005).

$\mathrm{Hu}$, Shaohua, Explaining Chinese Democratization (Santa Barbara: Praeger, 2000). Inglehart, Ronald, Welzel Christian, Modernization, Cultural Change and Democracy: The Human Development Sequence, (Cambridge: Cambridge University Press, 2005).

Jing, Yuejin, “Tenkei, Kyuushuu, Shintou: Chousen Kankyou kano Chuugoku Kyousantou no Soshikigijutu," [Transformation, Absorption and Penetration: Organizational Art of CCP under Challenge] in Hishida, Masaharu, ed., Chuugoku Kyousantou no Sabaibaru Senryaku [The CCP's Survival Strategy] (Tokyo: Sanwa 
Shoseki, 2012), pp. 127-174.

Kojima, Kazuko, “Eriitosou ni Okeru Tou no Sonzai” [CCP's Existence in Elite Strata] in Hishida, Masaharu, ed., Chuugoku Kyousantou no Sabaibaru Senryaku [The CCP's Survival Strategy] (Tokyo: Sanwa Shoseki, 2012), pp. 373-396.

Landry, Pierre F., Decentralized Authoritarianism in China; The Communist Party's Control of Local Elites in the Post-Mao Era (Cambridge: Cambridge University Press, 2008).

Pei, Minxin, "Is China Democratizing?” Foreign Affairs, 77-6 (November/December 1998), pp. 68-83.

Pei, Minxin, China's Trapped Transition: The Limits of Developmental Autocracy (Cambridge, MA,: Harvard University Press, 2006).

Pew Center Global Attitudes Project, 22-Nation Survey (Conducted April 7 - May 8 2010). Pew Research Center (Spring 2010) at <http://www.pewglobal.org/category/ datasets/2010/> (searched date: 27 April 2012).

Rowen, Henry S., “The Short March: China's Road to Democracy”, The National Interest (Fall 1996), pp. 61-70.

Senge, Peter M. The Fifth Discipline: The Art \& Practice of the Learning Organization, Doubleday (New York: 1992).

Shambaugh, David L., China's Communist Party: Atrophy and Adaptation (Berkeley, CA: University of California Press, 2008).

Zhu, Jianrong, "Touchuuou no Kenkyuu Kikan: Gakushuugata Seitou Kensetsu to Diaoyan Katsudou" [Research Organs in Party Central: Construction of Learning Party and Diaoyan Acitivity] in Hishida, Masaharu, ed., Chuugoku Kyousantou no Sabaibaru Senryaku [The CCP's Survival Strategy] (Tokyo: Sanwa Shoseki, 2012), pp. 61-102.

\section{About the Author}

Masaharu Hishida is Professor of Contemporary China Studies and Sociology in the Department of Law and Director of the Institute of Grassroots China at Hosei University. Professor Hishida studied at Peking University after graduating from Sociology Department, University of Tokyo. His research interests include state-society relations and social structure in contemporary China. Professor Hishida is a widely published author of numerous books, articles, book chapters, including Chuugoku Kyosanto no Sabaibaru Senryaku [CCP's Survival Strategy], Sanwa Shoseki, 2012, Chuugoku: Kisou Shakai no Gabanansu [Grassroots Governance in China], Hosei University Press, 2010, China's Trade Union:- How Autonomous are They? A Survey of 1811 Enterprise Union Chairpersons, Routledge, 2010, Keizai Hatten to Shakai 
Hendou [The Economic Growth and Social Development], co-authored with Shigeto Sonoda, Nagoya University Press, 2005, Chuugoku: Kokka tono Kyosei [China: State and Society Symbiotic Relations], Tokyo University Press, 2003.

Address: 2-17-1, Fujimi, Chiyoda-ku, Tokyo, 102-8160, Graduate School of Global Politics, Hosei University, Japan.

E-mail: hishida@hosei.ac.jp 